\title{
Black Metal, Literature and Mythology. The Case of Cornelius Jakhelln
}

\section{by Giuliano D'Amico}

Popular culture is a category of the learned. [...] The debates surrounding even the definition of popular culture engage a concept that attempts to define, characterize and name practices never designated by its actors as part of 'popular culture'. [...] One can reduce the innumerable definitions of popular culture to two great descriptive models. The first [...] conceives popular culture as a coherent and autonomous symbolic system that functions according to a logic absolutely foreign to those of literate culture. The second [...] perceives popular culture in its dependencies and deficiencies with respect to the dominant culture. On the one side, then, popular culture constitutes a world apart, closed on itself, independent. On the other, popular culture is completely defined by its distance from a cultural legitimacy of which it is deprived.[1]

In the above statement book historian Roger Chartier stresses an impasse that has long characterized the understanding of popular culture and popular music. Although popular culture and music are widely researched and taught in scholarly institutions, their very definition has not managed to shake off their dependency and inferiority to 'high' culture. The two traditional models, as suggested by Chartier, work well as long as popular and high culture function as two impenetrable and separate systems. Problems arise when popular culture starts dealing with discourses traditionally belonging to high culture. Thus, Chartier introduces the concept of appropriation, which 'involves a social history of the various uses [...] of discourses and models, brought back to their fundamental social and institutional determinants and lodged in the specific practices that produce them.'[2] In this article I shall focus on black metal's appropriation of literary and mythological discourses - and the other way around. Following Chartier, I wish to show how the borders between 'high' and 'popular' culture often become blurred, and to help raise a debate on black metal as an art form, a debate which is 'sorely needed.' [3] In fact, unlike many other forms of popular music, black metal has hardly been the object of scholarly interest: Cornelius Jakhelln's activity as both writer and musician looks like a unique case in point for raising attention.

Black metal is a sub-genre of heavy metal music and was invented in the early 1980 os by, among others, British band Venom (who released an album entitled Black Metal), Sweden's Bathory and Norway's Mayhem. Black metal knew a flourishing period (often named 'the second wave of black metal') between 1990 and 1995, especially in Norway. Bands and records from this period are probably the most known worldwide, also because of the criminal offences perpetrated by some musicians involved in the scene (among others, the murder of Øystein Aarseth, founder of Mayhem and the burning of several churches). 
Attempting a definition of black metal is no simple task. According to Keith KahnHarris, author of a remarkable essay on the genre, black metal is traditionally 'characterized by screamed, high-pitched vocals, extremely rapid tempos, 'tremolo' riffs, a 'trebly' guitar sound, and simple production values.' [4] As far as the aesthetics of the genre are concerned, Kahn-Harris mentions a 'discursive transgression' which embraces misanthropy, occultism, Satanism and paganism.[5] Especially in Scandinavian countries, the interest in paganism has led to a rediscovery and massive use of Norse mythical material; a new term ('Viking metal') was also coined to group those bands interested in Scandinavian pre-Christian religion, history and culture.[6] Writer and musician Cornelius Jakhelln started his career in 1995, when together with Lars Nedland he founded a black metal band named Solefald. As the band states on its official website, Solefald ('sunset') was 'stolen' from the homonymous painting by Norwegian artist Theodor Kittelsen. In this painting as Nedland explains, Kittelsen portrays the cycle of being, which was found a very fitting idea for the band.[7]Drawings representing the cycle of end/beginning - perfection - decline are to be found in many Solefald albums.

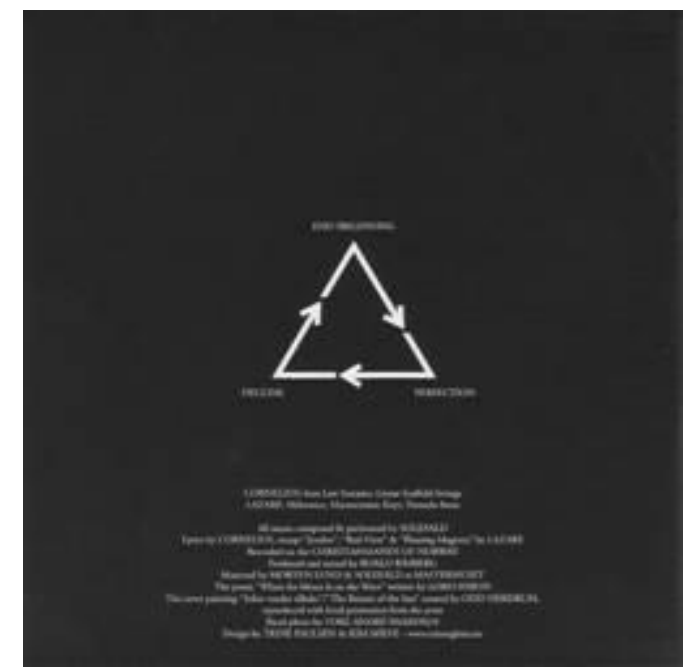

Solefald's debut album is dated 1997 and is entitled The Linear Scaffold (the picture to the left is taken from the inner sleeve and represents the cycle of being).[8] This album was quite unusual for the Norwegian black metal scene and signed Jakhelln's first experiment in blending black metal and literature. Norwegian black metal bands were still recovering from the negative media campaign of the mid-1990s. Most church burnings had taken place in 1992, the murder of Øystein Aarseth in 1993, and the incarceration of his murderer, Varg Vikernes, in 1994. Then Solefald entered the scene with a rather unexpected move. They elaborated a musical style 'ranging from rage and desperation to calm and atmospheric music. The band incorporated strange and nearly taboo techniques in the black metal scene of that time as well, using hand claps along with choruses [...], jazzy clean guitar passages, and intense shrieks over lush and peaceful piano pieces.'[9] Lyrically speaking, the band rejected the Satanic and antichristian attitude of most other bands and portrayed a sort of inner, imaginary journey from sunrise to sunset. In the booklet of the 2007 reprint of the album, the band made the following statement: 'From the actual moment of Sunrise - Lever du soleil - Sonnenaufgang - Soloppgang - navigation becomes possible and at the same time necessary for the voyager, as the world is slowly unveiled. There are many ways to express this latent will to explore: one is through the medium of poetry and its metaphors, another is through the use of music with its movement and its organisation of sounds.' $[10]$ The album is an experimental artwork in which poetry and music meet. Although this may sound banal, it is quite rare to find such an 
emphasis on the lyrical side of music among black metal bands. In most cases, the main focus of a black metal record is on music, while lyrics are dedicated to a more or less inconsistent worship of the forces of evil. Solefald maintained a musical link with black metal, but only to transcend its limits; they also coined a new term to define their music: 'red music with black edges'. 'Within these running minutes, time has been subdued by our passion, our desires - an expression thoroughly worked out by human mind and flesh. In terms of intensity and cruelty, the musical barbarity remains the same. It has, however, obtained a new and more sophisticated vehicle: The Linear Scaffold - The circular Drain. Sunset - Coucher du soleil Sonnenuntergang - Solefald'.[11] The band elaborated such claims in both music and lyrics: most of the songs, in fact, are poems by Cornelius Jakhelln put into music by Solefald. 'Tequila Sunrise', for instance, is a long erotic poem, sung against a background of charming and melancholic piano music. 'Philosophical revolt' is a journey into philosophic dichotomies, evoking Confucius and Lao Tse, Socrates and Plato, Schopenhauer and Nietzsche, Sartre and Beauvoir. The concluding song features Lord Byron's poem 'When the Moon is on the Wave' as lyrics, which also give the title to the song.

As soon as their debut album was released, Solefald chose an appropriation of literary, poetic and philosophical material which had little to do with the musical genre they belonged to and, whether consciously or not, they contributed to changing it. Yet, they went even further in their second album, Neonism, released in 1999[12]. As the band recalls on its site, the album was 'a hotchpotch of styles and feelings', 'incorporating black metal, pop, classical music, punk, progressive metal, and trip hop.' $[13]$ The album features repeated patterns of Hammond organ, clean vocals and jazzy rhythms, which were completely unconventional practices for black metal at that time. Such a variety of styles and atmospheres was also reflected in the lyrics, which, in Solefald's own words, 'were extremely unconventional for metal in general and black metal especially (since traditional black metal lyrics are more relevant to the $13^{\text {th }}$ century than the $20^{\text {th }}$ ), dealing with socio-political issues and pop culture criticism'. 14] Solefald seemed to describe another journey, not confined to the temporal space between sunrise and sunset, but one that widened the traveller's space from the past centuries to today. In fact, the cycle of being was once again a key concept, appearing in the cover artwork (2007 reissue).[15] 


\section{Nordicum-Mediterraneum}
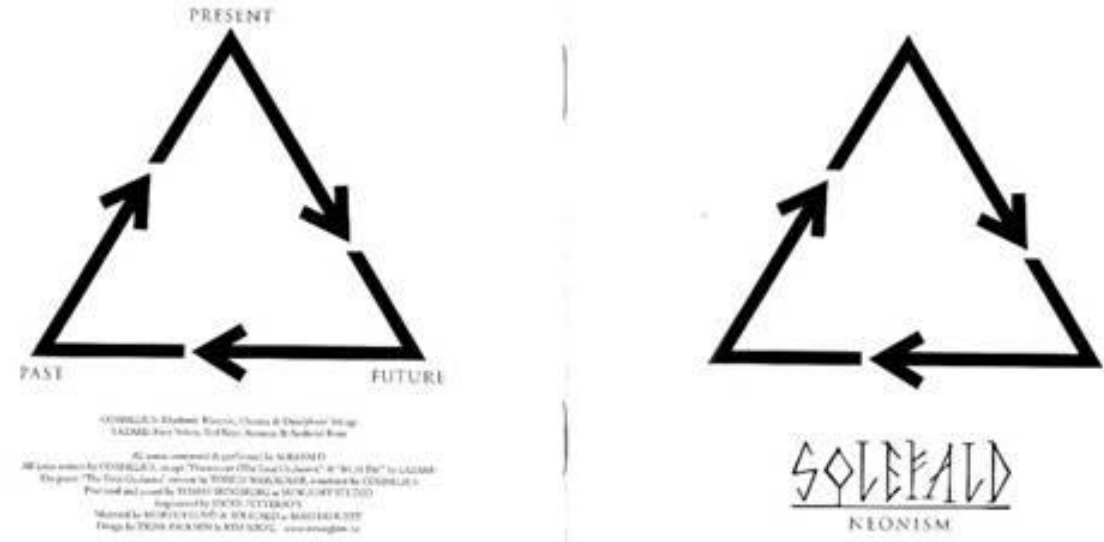

The three peaks of the triangle represent past, present and future, corroborating the interpretation of the album as a temporal journey. Lyrics were written in French and English and evoked images ranging from the United States to England, France and Africa, in a somewhat post-modern and grotesque portrait of a globalized world. The very first strophe of the opening song 'Proprietors of Red', which the band also enclosed as a disclaimer in the last page of the booklet, can work as a case in point: 'The world is my will and I will a cigar / A coronas corona creation of sound / Cedar matchsticks light the best Cuban brand / Hiroshima hides in this far Havana / A motion picture to rewind and remaster / The Director died in a Nietzschean crash / Franco American power première / CK II Chanel no. 6’.16]

Soon after the release of Neonism, Jakhelln started his career as a writer, publishing his first book Gebura Muse. Quadra Natura 0001.[17] It is a mixture of poems and prose, which is important to our subject in different ways. Firstly, it marked Jakhelln's first reference to mythology: Gebura Muse is the story of a djinn, a genie belonging to the Islamic tradition, which is named Ibliis and is sent to Earth by the Geburah, the fifth Sephiroth of the tree of life. In a way, Gebura Muse is comparable to Solefald's Neonism for its taste for travel narrative. Here we see Ibliis riding a Lamborghini Diablo in the USA, discussing Norwegian politics and turning into a Jim Morrison-like character. Furthermore, an intriguing token of intertextuality arises between Jakhelln's production as musician and poet. The poem 'Ned den kanelstrødde boulevarden til det kremfylte slottet' $[18]$ is a quite evident rewriting of Solefald's song 'Tequila Sunrise'. The same applies to the poem 'Nutrisco et exstinguo'[19], which bears the same title and directly refers to the opening song of Solefald's fourth album, In Harmonia Universali.[20]

After having changed record label, Solefald published a concept album entitled Pills for the Ageless Ills[21], which narrated 'the story of two brothers, Pornographer Cain and Philosopher Fuck, and the days before their deaths. Cain, a pornography director, is found guilty of the murder of Kurt Cobain. Meanwhile, Fuck is exiled from the United States and dies in a hospital in Paris. Both brothers represent the 
similarities and differences between desire and remorse in human nature.' $[22]$ Musically and lyrically close to both Neonism and Gebura Muse, Pills for the Ageless Ills was followed two years later by In Harmonia Universali, which contained Jakhelln's first direct reference to Nordic mythology. The second song of the album, in fact, is entitled Mont Blanc Providence Crow, and deals with a bird-like figure which can be clearly identified with Odin's raven Munin. Following Jakhelln's typical 'cosmopolitan' taste, this crow dwells on Mont Blanc in France, and acts as an 'observer to the Midgard of Men', controlling mankind. The band also shot a music video, which is a very good example of Solefald's 'red music with black edges', with its juxtaposition of harsh, black metal passages with Hammond organ and clean vocals. Red and black are also the main colours featured in the video.

From this point on, Jakhelln's interest in mythology grew and came to involve his entire artistic production. In 2004 and 2006 he published two other books of prose and poetry, intended to continue the quadrilogy started with Gebura Muse. The first book was entitled Yggdraliv. Quadra Natura O011,[23] a title which points at the tree of life of Nordic mythology, Yggdrasill, and is a sort of rewriting of the myths of creation, life and fall of the world. As in Gebura Muse, one of the main characters is an emissary of a deity (in this case Odin) named Adamat, a robot made up of wrecks. Interestingly, the phrase rødt for ild + svart for død[24] ('red for fire, black for death') serves as the opening line for the book and repeats the symbolic pattern which was already present in Solefald's albums. The following book, entitled Fagernorn. Quadra Natura 0111, 25] is divided in two parts, the first consisting of 'songs', or $k v a d$ by the Norse god Loki, and the second of a series of poems. The poems attributed to Loki seem to tell the story of Jakhelln himself, who travelled from Oslo to Paris in order to study philosophy, and found a completely new world down there. In any case, Jakhelln did not limit this reuse of mythical material to poetry alone. A significant effort was also made by Solefald. Between 2005 and 2006, the band released two albums, entitled Red for Fire. An Icelandic Odyssey part I[26] and Black for Death. An Icelandic Odyssey part II. [27] The juxtaposition of the two colours (which, as we have seen, have long been present in Solefald's aesthetics) is here endowed with both mythological and pagan connotations: red and black do not only symbolize fire and death, but also form the colours of the infernal lake in which the wolf Fenrir is chained. [28] Moreover, they are also the key-colours used in the pagan ritual of the Winter solstice.[29] The albums narrate the story of an Icelandic scald named Bragi. Although the name may recall both the Norse god of poetry and the scald Bragi Boddason often quoted in Snorri's Edda, this character seem to have little in common with them. In Red for Fire, Bragi is seduced by Disa, the White Frost Queen, wife to King Haukur. Wanting the queen for himself, the god Loki bans Bragi from Iceland and accuses him of having raped the queen, which makes Bragi an outlaw. Bragi has then to travel restlessly through Iceland, until Odin encourages him to travel back to Reykjavík and get his revenge. In the booklet of Black for Death, the story continues, but the narrator is Loki, who reports on Bragi's return to Reykjavík and on his death, which takes place together with king Haukur 's demise. Musically and lyrically, Red for Fire and Black for Death were quite puzzling for most Solefald fans. Solefald dropped most of the unconventional elements of their music and stuck 


\section{Nordicum-Mediterraneum}

to a more traditional form of black metal, allowing themselves only patterns of clean vocals and some excerpts of strings and saxophone as variations. The lyrics followed a narrative pattern that gave little space to speculation - the story is narrated as it is, as an Odyssey through an ancient time, with no pretension of having something to do with the present age. Jakhelln and Nedland also chose to wear Viking costumes in promotional photographs, as they were in vogue among Viking metal bands, which made quite a contrast to how they were used to appearing as a band (the pictures below show Solefald before and after the 'Viking' albums. Jakhelln is on the left in both of them).[30]
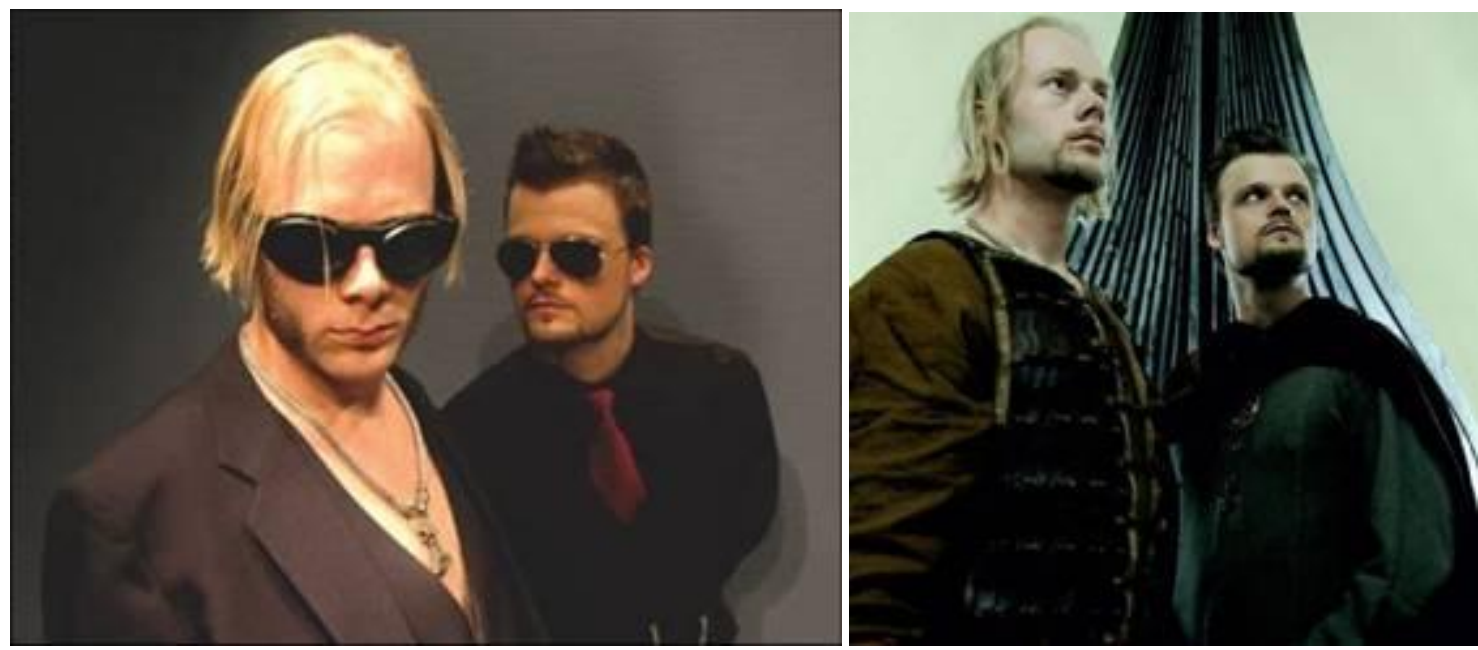

To most Solefald fans, these albums were difficult to tackle. After having taken up black metal, revolutionized and deconstructed it, they returned back to their roots, both lyrically and musically, releasing two albums which would fit in with the standards of the genre from ten years before. When asked about the reason for such a choice, the band answered, somewhat ironically, that 'Solefald was experimenting when everybody was being true. Now that things are changing and that we've pushed the experiment quite far already, we wanted Red For Fire and Black For Death to be our attempts at being true. This will be a true Nordic Viking Metal album.'[31] Not only did the band refer to a black metal 'trueness' they never shared (and to which I shall come back to) and to a subgenre - Viking metal - of which they never claimed to be a part; Solefald also dropped the old label 'red music with black edges' in favour of a more general 'avant-garde black metal', which stands both at the top of their official online biography and in the sleeves of their latest albums.

This return to the roots reached its peak between 2007 and 2008, when Jakhelln published the last part of his poetic tetralogy, Galderhug. Quadra Natura 1111 and his first novel, Gudenes Fall [The Fall of the Gods].[32] Galderhug is a collection of poems which are quite in keeping with Jakhelln's previous production, borrowing themes and models from Norse poetry yet trying to reinterpret them in a modern context. Galderhug is also Jakhelln's first attempt to reach readers outside the Norwegian market, as all poems were published in both Norwegian and English. More interesting for our subject is Jakhelln's sagaroman ('saga-novel') Gudenes Fall, 
where one is to find many of the characters who appeared in Jakhelln's poems and in Solefald's albums (for example Adamat from Yggdraliv, The Silver Dwarf from Black for death, and of course the Norse gods). After the dawn of Christendom in Norway, the Norse gods did not disappear, but had to move underground. They lead quite an apathetic life, playing blodball, a rather violent version of rugby, smoking cigars, discussing philosophy, having sex and playing music. Odin is planning a comeback on the Earth together with his friend, the silver dwarf Hornbore. Unfortunately, also the evil dwarf Regin has plotted to take control of the planet, which he plans to do using an army of robots. This will lead, inevitably, to a new ragnarök. In spite of the simple plot, Gudenes fall is extremely rich in themes and subplots, blending Wagner, Nietzsche, Christendom, paganism and Islam, Robbie Williams and black metal. The book also features a distinctively experimental use of language, as Jakhelln transcribed the characters' oral speeches into written language. Different characters speak in different Norwegian varieties or even in slang (for instance, Odin speaks a mixture of Oslo urban dialect and 'Norwegianized' English, while Loki speaks Danish).

In particular, one of Odin's favourite subjects of disputation is black metal. He elaborates on that in the following passage, in which I have maintained the original spelling for 'Norwegianized' English words:

There are two types of føkking sjittmettell: Blækk and ublækk. I think I prefer the blækk variant, but there is also much appreciable music in the ublækk. Ignorant outsiders say that føkking sjittmettell is only noise. I don't agree with them, as my point is that føkking sjittmettell is noise and music in proportional quantities. [...] Some of the føkking sjittmettallera wanted to add keyboards to their bands; among experts, they are called 'vimps' and 'påosers'. These expressions have no positive connotation. Having keyboards in a føkking sjittmettell-bænn, or even worse in a blækk føkking sjittmettell-bænn makes you lose recognition and prestige. In ublækk metal keyboards mean that you play too well. In blækk metal they mean that you play too bad.[33]

In the essay I mentioned at the beginning of my article, Keith Kahn-Harris has tried to describe the black metal scene by using Pierre Bourdieu's concept of 'field', i.e. basing his analysis on the recognition or 'cultural capital' individuals and bands acquire from recognized institutions in the field. [34] Within this framework, Jakhelln is referring to quite a hot debate in the black metal scene of the early Nineties, when more radical bands were accusing other members of the scene of corrupting black metal's 'trueness' and 'evilness' by the use of keyboards, and were therefore considered as 'posers'. [35] On the contrary, in the ublækk metal scene (which probably refers to other subgenres), keyboards were less controversially accepted and typically used by extremely technical bands (this is why they 'mean that you play too well'). Let us consider another excerpt:

Making pussies piss their pants in horror, this is what føkking sjittmettell is about, both blækk and ublækk. But there is a difference: [...] the ublækk metaler contents by 
acting as extremely tough, while the blækk metaler has to sit in jail to be extremely tough. And I don't mean sitting in jail because you've driven to fast, oh no. Blækk føkking is about sitting in jail because one is bad. Bad and biggtaim ivil.[36]

Here Jakhelln is referring to the murders and church burnings which were committed by members of the Norwegian black metal scene. In fact, much of the international success of Norwegian black metal is due to those criminal offences; without those facts, black metal would hardly have got the coverage in the media and the diffusion it has today. Half seriously, half ironically, Odin (and Jakhelln) seem to cast a critical yet fatherly look at the aesthetics of Norwegian black metal, which have long been focused on an extreme form of 'bodily transgression', which also included criminal acts.[37] In fact, in the Norwegian scene of the early Nineties, church burnings and other kinds of profanations were often preferred ways of accumulating cultural capital - Vikernes and other scene members who were imprisoned after having committed crimes were often hailed as scene leaders not because of their musical achievements, but primarily because of their criminal offences.

In any case, Norwegian black metal was also Jakhelln's primary source of inspiration as a musician - a source which he distorted, changed and finally returned to, releasing two albums of tru nårvidsjen blækk metæll.[38] If one considers the quotations above in the broader context of Jakhelln's production, a circle seems to close, intertextuality to have reached its peak. Modern, ancient literature and black metal are one in Jakhelln's work. He has been constantly bending towards literature when playing black metal, always towards black metal when writing literature. One could even stretch the argument as long as saying that much of Jakhelln's literature gets lost without a knowledge of black metal music: 'high' and 'popular' culture have mixed, and black metal has become a constitutive part of a literary project.

[1] Roger Chartier, Forms and Meanings, University of Pennsylvania Press, Philadelphia 1995, p. 83.

[2] Ibid., p. 89.

[3] Keith Kahn-Harris, Extreme Metal, Oxford, Berg 2007, p. 6.

[4] Ibid., p. 4.

[5] Ibid., pp. 34-43.

[6] Michael Moynihan and Didrik Søderlind, Lords of Chaos, Feral House, Venice (CA), 1998, pp. 171190.

[7] Steve Wiener/Solefald, "Biography', in www.solefald.no (site last visited on $10^{\text {th }}$ January 2009)

[8] The picture is reproduced by kind permission of Kim Sølve (www.trineogkim.no).

[9] Wiener/Solefald, op. cit.

[10] Solefald, The linear Scaffold, Avantgarde Music, Milan 1997 (quoted from the 2007 reissue).

[11] Ibid.

[12] Solefald, Neonism, Avantgarde Music, Milan, 1999 (reissued 2007).

[13] Wiener/Solefald, op.cit.

[14] Ibid.

[15] The picture is reproduced by kind permission of Kim Sølve (www.trineogkim.no).

[16] Solefald, Neonism, cit.

[17] Cornelius Jakhelln, Gebura Muse. Quadra Natura ooo1, Aschehoug, Oslo 2001.

[18] Ibid., p. 29.

[19] Ibid., p. 67. 
[20] Solefald, In Harmonia Universali, Century Media Records, Dortmund 2003.

[21] Solefald, Pills for the Ageless Ills, Century Media Records, Dortmund 2001.

[22] Wiener/Solefald, op. cit.

[23] Jakhelln, Yggdraliv. Quadra Natura oo11, Tiden Norsk Forlag, Oslo 2004.

[24] Ibid., p.1.

[25] Jakhelln, Fagernorn. Quadra Natura o111, Tiden Norsk Forlag, Oslo 2006.

[26] Solefald, Red For Fire. An Icelandic Odyssey part I, Season of Mist, Marseille 2005.

[27] Solefald, Black for Death. An Icelandic Odyssey part II, Season Of Mist, Marseille 2006.

[28] See Gianna Chiesa Isnardi, I miti nordici, Longanesi, Milan, 1991, pp. 470-1 and 472-3.

[29] http://paganistforbundet.org/ritualer/midtvinter.html (site last visited on $17^{\text {th }}$ January 2009).

[30] The picture on the left is taken from the World Wide Web. The one on the right is taken from

Solefald's official page www.solefald.no.

[31] Wiener/Solefald, op.cit.

[32] Jakhelln, Galderhug. Quadra Natura 1111. Cappelen Damm, Oslo 2008 and Gudenes Fall, Cappelen, Oslo 2007.

[33] Jakhelln, Gudenes Fall, pp. 104-105. Both translation and italics are mine.

[34] For more information see my review of the book in Nordicum-Mediterraneum, 3(1):

http://nome.unak.is/nome2/issues/vol3 1/damico.html (site last checked on 17 J January 2009)

[35] See, among others, Moynihan/Søderlind, op. cit., pp. 59-60 and 75-76.

[36] Jakhelln, Gudenes Fall, p. 105. Both translation and italics are mine.

[37] Kahn-Harris, op. cit., pp. 45-46.

[38] The phrase is taken from Ibid., p. 106. Italics are mine.

Giuliano D'Amico is a research fellow at the University of Oslo, where he is working on a PhD project on Enrico Polese Santarnecchi, an early Italian Ibsen translator and middleman. His main fields of interest are Scandinavian translations, reception studies and history of the book. 